\title{
Effect of Oral Clonidine on Hemodynamic Changes Due to Laryngoscopy, Intubation and Operative Procedures Stress Response
}

\section{Jehangir $\mathrm{AB}^{1 *}$, Roshan Ara ${ }^{1}$ and Mushtaq $\mathrm{SM}^{2}$}

${ }^{1}$ Kurji Holy Family Hospital, Patna, Bihar, India

${ }^{2}$ Malla Reddy Narayan Multispeciality Hospital, Telangana, India

*Corresponding author: Jehangir Allam Bhat, Kurji Holy Family Hospital, Patna, Bihar, India, Tel: 917033203315; Email: ajaalam333@gmail.com

\section{Research Article}

Volume 3 Issue 4

Received Date: October 27, 2018

Published Date: November 12, 2018

DOI: $10.23880 /$ apct- 16000140

\section{Abstract}

Context: Endotracheal intubation constitutes a period of extreme hemodynamic stress. Clonidine, $\alpha 2$ adrenergic agonist, slows down the heart rate and leads to a dose dependent decrease in systolic and diastolic blood pressure. It has $100 \%$ bioavailability following oral administration.

Aims: Effect of oral clonidine on hemodynamic changes due to laryngoscopy, Intubation and operative procedures stress response.

Setting and Design: This was prospective, randomized controlled, double-blind study.

Materials and Methods: Fifty patients of either sex, aged 18-45 years, ASA grade I/II undergoing elective surgeries under general anesthesia were included. Group A received Clonidine $4 \mathrm{mcg} / \mathrm{kg}$ orally induction and group B received $5 \mathrm{ml}$ distilled water. Heart rate (HR), systolic blood pressure (SBP), diastolic blood pressure (DBP), mean arterial pressure, and rate pressure product were noted at baseline, preinduction, postinduction, intubation and thereafter, 1, $3,5,10,15,20,25$ and $30 \mathrm{~min}$ following intubation.

Results: There was a statistically significant difference in heart rate, systolic, diastolic, mean arterial pressure and rate pressure product between two groups. Clonidine group had more stable hemodynamic parameters throughout.

Conclusion: Oral clonidine premedication in the dose of $4 \mathrm{mcg} / \mathrm{kg}$ can effectively attenuate the hemodynamic stress response during laryngoscopy, intubation and operative procedures.

Keywords: Oral Clonidine; Intubation; Laryngoscopy; Pre-Induction 


\section{Advances in Pharmacology and Clinical Trials}

\section{Introduction}

Induction of general anaesthesia, direct laryngoscopy and endotracheal intubation induce marked cardiovascular changes as well as autonomic reflex activity [1]. Laryngoscopy with or without tracheal intubation amounts to a highly noxious stimulus to the homeostasis of the patient. Many a time under lighter planes of anaesthesia it elicits a defence mechanism in the form of haemodynamic response to stress, which involves activation of adrenocortical system [2]. The response may be particularly hazardous for patients with cardiovascular and cerebrovascular diseases [3].

Hypertension, arrhythmias and myocardial ischemia induced by endotracheal intubation are the results of a reflex increase in sympathetic and sympathoadrenal activity [4]. Attenuation of these hemodynamic responses is of great importance in prevention of per operative morbidity and mortality. Strategies to circumvent these changes have included minimizing the duration of laryngoscopy, IV narcotics, IV and topical lignocaine, vasodilators, $\beta$-blockers, calcium channel blockers, inhaled anaesthetics and epidural analgesia. Although these drugs did obtund the cardiovascular response, they failed to fulfill the desired criteria of complete attenuation [5].

Recently there has been considerable research in the $\alpha 2$ adrenergic agonist group of drugs in this respect. These drugs act at receptor site in medulla oblongata and presynaptically at peripheral nerve terminals, to cause a reduction in activity of sympathetic nervous system [6]. Clonidine, an imidazole compound is a selective agonist for $\alpha 2$ adrenoceptors with a ratio of 200:1 ( $\alpha 2$ : $\alpha 1)$. Though primarily an antihypertensive, clonidine has been increasingly used for premedication [7,8]. Its central action reduces sympathetic activity, producing sedation, anxiolysis, dryness of secretions with reduction in requirement of anesthetic agents and improved cardiovascular stability in the perioperative period [9].
Clonidine premedication attenuates potentially harmful cardiovascular responses and hypertension during laryngoscopy and intubation [10]. Within the last decade, several studies have reported the successful use of oral clonidine premedication to prevent hyperadrenergic and hyperdynamic cardiovascular responses to endotracheal intubation $[11,12]$.

\section{Materials and Methods}

A prospective double-blind randomized control study was conducted after taking clearance from institutional ethical committee and proper consent. Patients who were ASA I and II of either sex and age group between 18-45yrs undergoing elective orthopedic, spine, Otorhinolaryngology, gynecological and general surgical procedures under general anaesthesia. The study population was subdivided into 2 groups of 50 patients each. GROUP I (oral Clonidine group) received Tab Clonidine $4 \mu \mathrm{g} / \mathrm{kg}$ orally $60 \mathrm{~min}$ before induction with sips of water. GROUP II (control group) receives $5 \mathrm{ml}$ distilled water $15 \mathrm{~min}$ before induction. Blood pressure (SBP, DBP, MBP) via NIBP and Heart rate through continuous ECG monitoring recorded by a single observer, preinduction, post induction(pre-laryngoscopy) and at one, two, three and five minutes after laryngoscopy and intubation in both groups. Subsequently every 5 minutes till 30 minutes intra operatively.

\section{Statistical Methods}

Analysis was done by descriptive data presented as Mean \pm SD. Pair wise comparison between the groups was done by "T" test. For all tests $\mathrm{P}$ value of $<0.05$ will be considered significant.

\section{Results}

The two groups were statistically comparable with respect to age, sex, weight, and American Society of Anesthesiologists (ASA) physical status as in Table 1.

\begin{tabular}{|c|c|c|c|c|c|c|}
\hline Parameters & \multicolumn{2}{|c|}{ Control Group A } & \multicolumn{2}{|c|}{ Oral Clonidine Group B } & Mean Deviation & P Valve \\
\hline \multirow{2}{*}{ Gender } & Male & 32 & Male & 40 & & \multirow{2}{*}{0.56} \\
\hline & Female & 28 & Female & 10 & & \\
\hline Age Mean \pm Sd & \multicolumn{2}{|c|}{$33.02 \pm 9.23$} & \multicolumn{2}{|c|}{$31.60 \pm 8.74$} & 1.42 & 0.432 \\
\hline Height Mean \pm Sd & \multicolumn{2}{|c|}{$158.96 \pm 5.48$} & \multicolumn{2}{|c|}{$160.26 \pm 5.08$} & -1.30 & 0.222 \\
\hline Weight Mean \pm Sd & \multicolumn{2}{|c|}{$62.30 \pm 12.06$} & \multicolumn{2}{|c|}{$63.62 \pm 10.61$} & -1.32 & 0.563 \\
\hline
\end{tabular}

Table 1: Demographic Profile. 


\section{Advances in Pharmacology and Clinical Trials}

\section{Heart Rate}

Pre-induction heart rate (before receiving clonidine or placebo) was $79.6 \pm 5.95$ in group A \& $83.3 \pm 8.73$ in group
B with mean difference of - 3.78. This difference was statistically insignificant with $P$ value of 0.13 as shown in Table 2/Figure 1.

\begin{tabular}{|c|c|c|c|c|c|c|}
\hline \multirow[t]{2}{*}{ Heart Rate } & \multirow{2}{*}{$\begin{array}{c}\text { Group A } \\
\text { Mean } \pm \text { Sd }\end{array}$} & \multirow{2}{*}{$\begin{array}{l}\text { Group B } \\
\text { Mean } \pm S d\end{array}$} & \multirow{2}{*}{$\begin{array}{c}\text { Mean } \\
\text { Difference }\end{array}$} & \multicolumn{2}{|c|}{$\begin{array}{c}\text { 95\% Confidence Interval of } \\
\text { Difference }\end{array}$} & \multirow{2}{*}{$\begin{array}{c}\mathbf{P} \\
\text { Value }\end{array}$} \\
\hline & & & & Lower & Upper & \\
\hline Pre- Induction & $79.6 \pm 5.95$ & $83.3 \pm 8.73$ & -3.78 & -6.75229 & -0.81269 & 0.013 \\
\hline $\begin{array}{c}\text { Post Induction } \\
\text { (Pre-Laryngescopy) }\end{array}$ & $83.4 \pm 5.19$ & $76.7 \pm 8.86$ & 6.72 & 3.82852 & 9.60286 & 0.001 \\
\hline $\begin{array}{l}\text { Post Induction } \\
\text { Post Laryngescopy } \\
\text { and Intubation }\end{array}$ & $92.22 \pm 9.70$ & $77.14 \pm 6.28$ & 15.08 & 11.82828 & 18.3249 & 0.0008 \\
\hline 1 Minute & $90.14 \pm 8.10$ & $80.16 \pm 8.09$ & 15.08 & 6.76342 & 13.19658 & 0.002 \\
\hline 2 Minutes & $88.46 \pm 7.25$ & $82.46 \pm 7.25$ & 9.98 & 3.12093 & 8.87907 & 0.0004 \\
\hline 3 Minutes & $86.78 \pm 6.79$ & $80.78 \pm 6.79$ & 6.00 & 3.30302 & 8.69698 & 0.003 \\
\hline 5 Minutes & $86.80 \pm 6.28$ & $77.92 \pm 6.61$ & 6.00 & 6.31976 & 11.44016 & 0.0008 \\
\hline 10 Minutes & $92.32 \pm 4.92$ & $74.32 \pm 5.78$ & 8.88 & 6.53734 & 11.46266 & 0.0009 \\
\hline 15 Minutes & $84.7 \pm 6.47$ & $75.7 \pm 6.89$ & 9.00 & 16.04665 & 19.95335 & 0.0002 \\
\hline 20 Minutes & $83.20 \pm 4.54$ & $73.2 \pm 5.43$ & 18.00 & 8.19451 & 11.80549 & 0.004 \\
\hline 25 Minutes & $85.34 \pm 4.11$ & $72.34 \pm 4.31$ & 13.00 & 11.36532 & 14.63468 & 0.0008 \\
\hline 30 Minutes & $84.38 \pm 3.10$ & $71.38 \pm 3.10$ & 13.00 & 11.76586 & 14.23414 & 0.0007 \\
\hline
\end{tabular}

Group A = Controls, Group B = Oral clonidine group

Table 2: Comparison of Mean Heart rate (HR) between two groups.

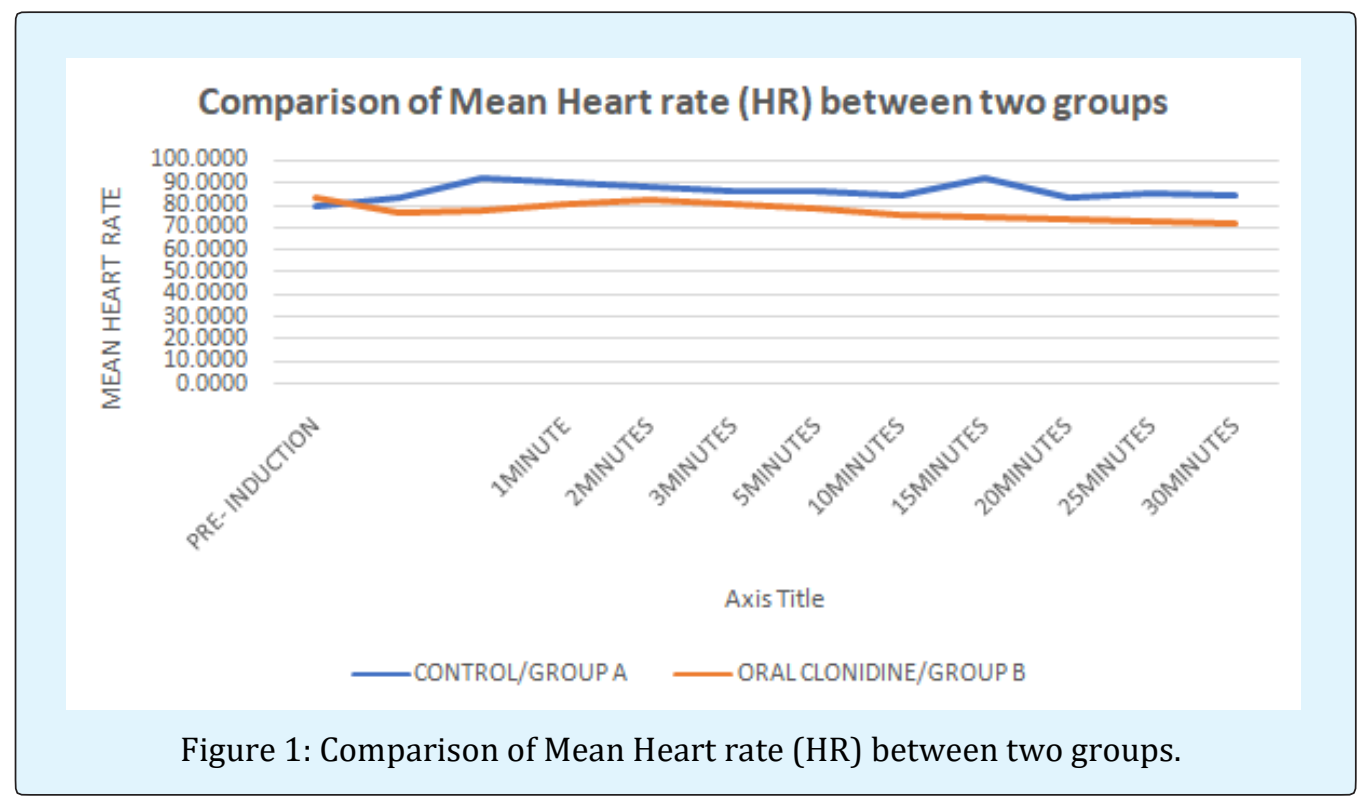

After the administration of drug (clonidine) in Group B and placebo in Group A, Group A showed lot of fluctuations in HR but, HR in Group B was well under control in normal range as per the age. Which was proved but statistical significance of mean differences at various times intervals with $P$ valve less than 0.005 at all intervals as shown in Table 2/Figure 1. 


\section{Advances in Pharmacology and Clinical Trials}

\section{Systolic Blood Pressure}

Pre- induction difference in systolic blood pressure (SBP) between two groups was 4.56(124.8-120.2) was statistically insignificant ( $p$ value 0.008 ) as shown in Table 3/Figure 2 .

The highest mean SBP $133.26 \pm 00(\mathrm{mmHg})$ belonged to placebo group at post induction, post laryngoscopy and intubation time and the lowest one was at $30 \mathrm{mins}$ after drug administration in Group B. Group A showed marked variation in SBP throughout the operative procedures, while Group A under effect of clonidine showed controlled SBP with no patient shooting SBP into hypertensive range. Differences in SBP since from post induction period up to end of time limit of study period were statistically significant with $\mathrm{p}$ value of less than 0.005 as shown in data in Table 3/Figure 2.

\begin{tabular}{|c|c|c|c|c|c|c|}
\hline \multirow{2}{*}{ Systolic Blood Pressure } & \multirow{2}{*}{$\begin{array}{c}\text { Group A } \\
\text { Mean } \pm \text { Sd }\end{array}$} & \multirow{2}{*}{$\begin{array}{c}\text { Group B } \\
\text { Mean } \pm \text { Sd }\end{array}$} & \multirow{2}{*}{$\begin{array}{c}\text { Mean } \\
\text { Difference }\end{array}$} & \multicolumn{2}{|c|}{$\begin{array}{l}\text { 95\% Confidence Interval } \\
\text { of Difference }\end{array}$} & \multirow{2}{*}{$\begin{array}{c}\mathbf{P} \\
\text { Value }\end{array}$} \\
\hline & & & & Lower & Upper & \\
\hline Pre- Induction & $124.8 \pm 5.84$ & $120.2 \pm 10.27$ & 4.56 & 1.23306 & 7.87608 & 0.008 \\
\hline $\begin{array}{l}\text { Post Induction (Pre- } \\
\text { Laryngescopy) }\end{array}$ & $126.7 \pm 3.50$ & $114.38 \pm 10.02$ & 12.32 & 9.31415 & 15.30311 & 0.0002 \\
\hline $\begin{array}{l}\text { Post Induction Post } \\
\text { Laryngescopy and } \\
\text { Intubation }\end{array}$ & $133.26 \pm 8.00$ & $125.26 \pm 8.00$ & 8.00 & 4.82403 & 11.17597 & 0.001 \\
\hline 1 Minute & $128.96 \pm 8.38$ & $120.96 \pm 8.38$ & 8.00 & 4.67359 & 11.32641 & 0.003 \\
\hline 2 Minutes & $127.86 \pm 7.76$ & $117.86 \pm 7.76$ & 8.00 & 6.91835 & 13.08165 & 0.0009 \\
\hline 3 Minutes & $123.60 \pm 10.11$ & $113.60 \pm 10.12$ & 10.00 & 5.98356 & 14.01644 & 0.002 \\
\hline 5 Minutes & $124.02 \pm 6.48$ & $114.02 \pm 6.52$ & 10.00 & 7.42722 & 12.57278 & 0.0007 \\
\hline 10 Minutes & $120.06 \pm 6.68$ & $110.06 \pm 6.97$ & 10.00 & 7.21376 & 12.78624 & 0.004 \\
\hline 15 Minutes & $120.94 \pm 7.08$ & $110.94 \pm 8.78$ & 10.00 & 7.2756 & 12.7244 & 0.0006 \\
\hline 20 Minutes & $118.68 \pm 6.25$ & $108.68 \pm 6.47$ & 10.00 & 7.52927 & 12.47073 & 0.001 \\
\hline 25 Minutes & $117.48 \pm 6.96$ & $106.48 \pm 6.07$ & 11.00 & 8.23713 & 13.76287 & 0.0019 \\
\hline 30 Minutes & $116.78 \pm 6.56$ & $104.78 \pm 6.56$ & 12.00 & 9.39519 & 14.60481 & 0.0018 \\
\hline
\end{tabular}

Group A = Controls, Group B = Oral clonidine group

Table 3: Comparison of Mean SBP ( $\mathrm{mm} \mathrm{Hg}$ ) between two groups.

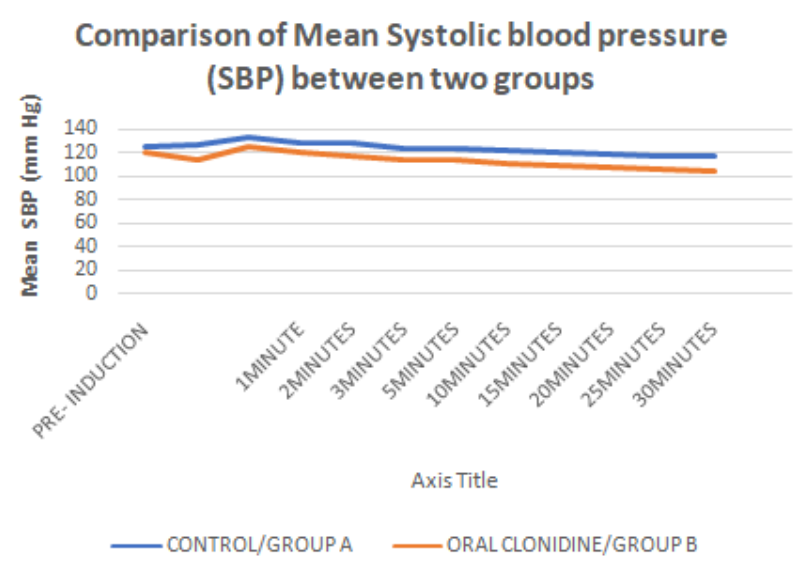

Figure 2: Comparison of Mean Systolic blood pressure (SBP) between two groups. 


\section{Advances in Pharmacology and Clinical Trials}

\section{Diastolic Blood Pressure}

Pre- induction mean difference in systolic blood pressure (DBP) between two groups was nearly zero which was statistically insignificant ( $p$ value 1 ) as shown in Table 4/Figure 3.

The highest mean DBP $86.62 \pm 8.22$ (mmHg) belonged to placebo group at post induction, post laryngoscopy and intubation time and the lowest one was at 30mins after drug administration in Group B with highest mean difference between two groups of 12.00 ( $\mathrm{mm} \mathrm{hg}$ ). Group A showed marked variation in DBP throughout the operative procedures, while Group A under effect of clonidine showed controlled DBP. Differences in DBP since from post induction period up to end of time limit of study period were statistically significant with $p$ value of less than 0.005 as shown in data in Table 4/ Figure 3.

\begin{tabular}{|c|c|c|c|c|c|c|}
\hline \multirow{2}{*}{$\begin{array}{l}\text { Diastolic Blood } \\
\text { Pressure }\end{array}$} & \multirow{2}{*}{$\begin{array}{c}\text { Group A } \\
\text { Mean } \pm \text { Sd }\end{array}$} & \multirow{2}{*}{$\begin{array}{c}\text { Group B } \\
\text { Mean } \pm S d\end{array}$} & \multirow{2}{*}{$\begin{array}{c}\text { Mean } \\
\text { Difference }\end{array}$} & \multicolumn{2}{|c|}{$\begin{array}{c}\text { 95\% Confidence } \\
\text { Interval of Difference }\end{array}$} & \multirow[t]{2}{*}{$P$ Value } \\
\hline & & & & Lower & Upper & \\
\hline Pre- Induction & $79.4 \pm 8.17$ & $79.4 \pm 8.17$ & 0 & -3.24624 & 3.24624 & 1 \\
\hline $\begin{array}{l}\text { Post Induction (Pre- } \\
\text { Laryngescopy) }\end{array}$ & $82.64 \pm 6.3$ & $70.12 \pm 7.55$ & 12.52 & 9.74459 & 15.29443 & 0.0004 \\
\hline $\begin{array}{l}\text { Post Induction Post } \\
\text { Laryngescopy and } \\
\text { Intubation }\end{array}$ & $86.62 \pm 8.22$ & $80.04 \pm 9.18$ & 6.58 & 3.11904 & 10.04043 & 0.0017 \\
\hline 1 Minute & $81.92 \pm 8.08$ & $75.92 \pm 8.08$ & 6.58 & 2.79278 & 9.20722 & 0.0014 \\
\hline 2 Minutes & $82.56 \pm 8.82$ & $72.56 \pm 8.82$ & 6 & 6.49734 & 13.50266 & 0.0005 \\
\hline 3 Minutes & $82.82 \pm 10.57$ & $72.82 \pm 10.57$ & 10.00 & 5.80221 & 14.19779 & 0.0012 \\
\hline 5 Minutes & $81.18 \pm 7.43$ & $71.18 \pm 7.64$ & 10.00 & 7.04763 & 12.95237 & 0.0004 \\
\hline 10 Minutes & $79.42 \pm 6.29$ & $69.42 \pm 7.89$ & 10.00 & 7.59628 & 12.40372 & 0.0001 \\
\hline 15 Minutes & $81.12 \pm 6.98$ & $71.12 \pm 7.67$ & 10.00 & 7.50255 & 12.49745 & 0.0002 \\
\hline 20 Minutes & $78.32 \pm 6.24$ & $68.32 \pm 6.34$ & 10.00 & 7.52278 & 12.47722 & 0.004 \\
\hline 25 Minutes & $79.44 \pm 4.58$ & $68.44 \pm 4.58$ & 11.00 & 9.18181 & 12.81819 & 0.0028 \\
\hline 30 Minutes & $79.78 \pm 5.07$ & $67.78 \pm 5.07$ & 12.00 & 9.98692 & 14.01308 & 0.0034 \\
\hline
\end{tabular}

Group A = Controls, Group B = Oral clonidine group

Table 4: Comparison of Mean DBP (mm Hg) between two groups.

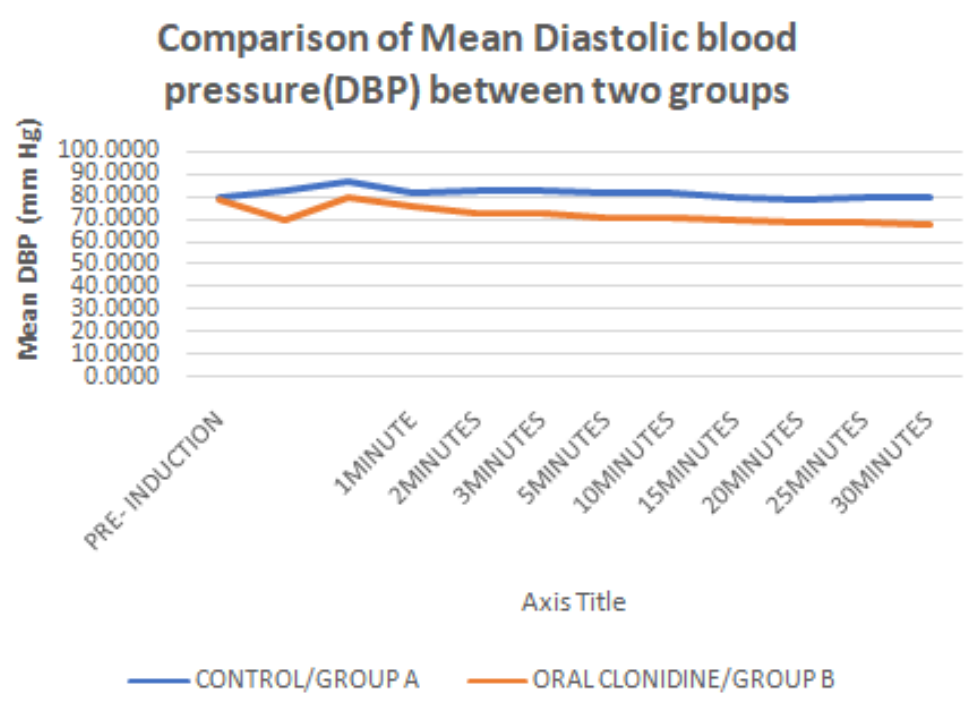

Figure 3: Comparison of Mean Diastolic blood pressure (DBP) between two groups. 


\section{Advances in Pharmacology and Clinical Trials}

\section{Mean Areterial Pressure}

Pre- induction difference in mean arterial pressure (MAP) between two groups was 3.833(94.5-90.7) was statistically insignificant ( $p$ value 0.010 ) as shown in Table 5/Figure 4.

The highest mean MAP (mmHg) 102.16 \pm 7.17 was recorded in placebo group at post induction, post laryngoscopy and intubation time and the lowest one was at 30mins after drug administration in Group $\mathrm{B}(75.52 \pm 6.59 \mathrm{mmHg})$. Group A showed marked variation in MAP throughout the operative procedures, while Group A under effect of clonidine showed controlled MAP. Differences in MAP since from post induction period up to end of time limit of study period were statistically significant with $\mathrm{p}$ value of less than 0.005 as shown in data in Table 5/Figure 4.

\begin{tabular}{|c|c|c|c|c|c|c|}
\hline \multirow{2}{*}{$\begin{array}{l}\text { Mean Arterial } \\
\text { Pressure }\end{array}$} & \multirow{2}{*}{$\begin{array}{c}\text { Group A } \\
\text { Mean } \pm \text { Sd }\end{array}$} & \multirow{2}{*}{$\begin{array}{c}\text { Group B } \\
\text { Mean } \pm \text { Sd }\end{array}$} & \multirow{2}{*}{$\begin{array}{c}\text { Mean } \\
\text { Difference }\end{array}$} & \multicolumn{2}{|c|}{$\begin{array}{c}\text { 95\% Confidence Interval } \\
\text { Of Difference }\end{array}$} & \multirow[t]{2}{*}{ P Value } \\
\hline & & & & Lower & Upper & \\
\hline Pre- Induction & $94.5 \pm 5.38$ & $90.7 \pm 8.81$ & 3.83333 & 0.92763 & 6.73148 & 0.01 \\
\hline $\begin{array}{l}\text { Post Induction (Pre- } \\
\text { Laryngescopy) }\end{array}$ & $97.3 \pm 4.1$ & $83.92 \pm 8.67$ & 13.40667 & 10.68891 & 16.11131 & 0.0013 \\
\hline $\begin{array}{l}\text { Post Induction Post } \\
\text { Laryngescopy And } \\
\text { Intubation }\end{array}$ & $102.16 \pm 7.17$ & $90.76 \pm 9.00$ & 11.40667 & 8.17439 & 14.63693 & 0.00043 \\
\hline 1 Minute & $97.6 \pm 7.41$ & $87.80 \pm 8.88$ & 11.4 & 6.54971 & 13.04899 & 0.0007 \\
\hline 2 Minutes & $97.66 \pm 7.91$ & $84.12 \pm 9.14$ & 9.8 & 10.14552 & 16.9336 & 0.0003 \\
\hline 3 Minutes & $96.41 \pm 7.68$ & $82.08 \pm 8.71$ & 13.54 & 11.07141 & 17.59462 & 0.0018 \\
\hline 5 Minutes & $95.46 \pm 6.63$ & $81.00 \pm 7.43$ & 14.33 & 11.68994 & 17.22975 & 0.0018 \\
\hline 10 Minutes & $92.96 \pm 5.86$ & $78.68 \pm 6.97$ & 14.46 & 11.99398 & 16.87186 & 0.0004 \\
\hline 15 Minutes & $94.39 \pm 5.71$ & $79.96 \pm 6.56$ & 14.43 & 11.72725 & 16.84513 & 0.0019 \\
\hline 20 Minutes & $91.77 \pm 5.62$ & $77.5000 \pm 8.85$ & 14.28 & 11.77789 & 16.76764 & 0.0009 \\
\hline 25 Minutes & $92.12 \pm 4.97$ & $77.0 \pm 5.78$ & 15.12 & 12.97874 & 17.26066 & 0.0034 \\
\hline 30 Minutes & $92.1 \pm 5.14$ & $75.52 \pm 6.59$ & 16.59 & 14.24562 & 18.93931 & 0.0014 \\
\hline
\end{tabular}

Group A = Controls, Group B = Oral clonidine group

Table 5: Comparison of Mean MAP ( $\mathrm{mm} \mathrm{Hg}$ ) between two groups.

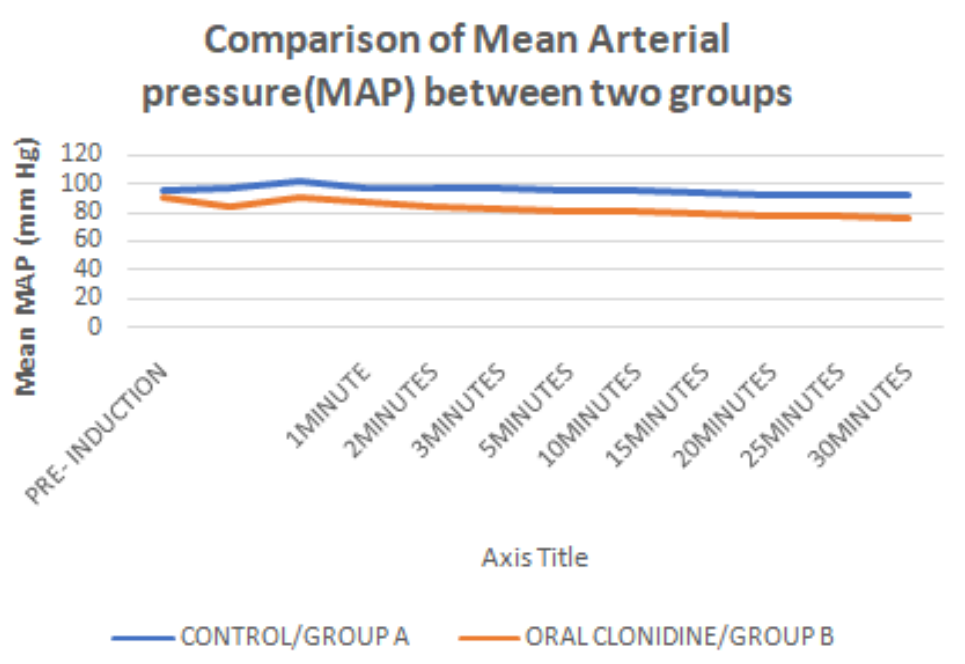

Figure 4: Comparison of Mean Arterial pressure (MAP) between two groups. 


\section{Advances in Pharmacology and Clinical Trials}

\section{Discussion}

It is a well-established fact that laryngoscopy and endotracheal intubation act as mechanical stimuli to activate a reflex, mediated by the sympatho-adrenal axis and causes significant hemodynamic stress [13-15]. Airway instrumentation leads tostimulation of nerves that carry afferent impulses to the vasomotor center located in brain stem which in turn activates the sympatho-adrenal system to release catecholamines resulting in increase in the heart rate and blood pressure. There is a significant association between incidence of myocardial infarction and tracheal intubation or extubation [16]. It may also lead to potentially dangerous rise in intracranial and intraocular pressures. Various pharmacologic agents like beta blockers, lignocaine, and calcium channel blockers, ganglion blocking drugs, vasodilators, opioids, and $\alpha 2$-adrenergic agonist have been tried to attenuate this hemodynamic response with varying success.

Clonidine is an imidazoline derivative with selective agonisticaction at $\alpha 2$ adrenergic receptors. Its mechanism of actioninvolves stimulation of central $\alpha 2$ adrenergic receptors in the vasomotor center of medulla and presynaptically at the peripheral nerve terminals, blocking release of norepinephrine from the nerve terminals leading to hypotension and bradycardia. It also stimulates parasympathetic outflow, increasing vagal tone contributing to the slowing of HR [17]. When given orally, its bioavailability is $100 \%$.

We chose $4 \mathrm{mcg} / \mathrm{kg}$ as the dose of clonidine in accordance with previous studies demonstrating safety with lower incidence of obvious side effects like severe bradycardia and hypotension [18]. Clonidine blunts the reflex tachycardia associated with direct laryngoscopy and tracheal intubation [19]. Suggested that cardiovascular responses by short lasting laryngoscopies can be attenuated with very low doses of oral clonidine. It also decreases the intra operative lability of heart rate. In Group A (control group), there were wide variation in heart rate during entire operative procedure especially increments in heart rate during laryngoscopy and intubation. But, in Group B (oral clonidine group) heart rate well controlled. These findings corroborated the studies of Roy \& Rudra [20], Raval, et al. [7], Joshi, et al. [21].

There was a slight increase in mean systolic blood pressure (SBP), mean diastolic pressure (DBP) and mean arterial pressure (MAP)at post induction post laryngoscopy and intubation both the groups. In the
Clonidine group this rise was not as significant as nonclonidine group. Rest during the entire operative procedure all parameters, mean systolic blood pressure (SBP), mean diastolic pressure (DBP) and mean arterial pressure (MAP) were well controlled in clonidine group and showed marked fluctuations in control group. On analysing these observations, it can be concluded that Clonidine reduces the systolic as well as diastolic blood pressure in operative period. These observations strongly reflect the hypotensive effects of Clonidine and its ability to attenuate rise in SBP during laryngoscopy and intubation. These findings were in agreement with the studies conducted by Das, et al. [22], Raval, et al. [7]. It can be concluded that Clonidine by virtue of its hypotensive effects, systolic more than diastolic, controls the rise in MAP in the study group that was on clonidine premedication. These findings correlate with those of Joshi VS, et al [22], Raval et al. [7].

\section{Acknowledgements}

We are highly thankful to our senior consultant without their esteemed support this research was not possible. We, also thank to our paramedic staff and hospital statistician for his valuable effort for analysing the research data.

\section{Conclusion}

To conclude oral clonidine at dose of $3 \mathrm{mcg}$ can effectively attenuate the hemodynamic response in operative procedures in adults.

\section{References}

1. Fleisher LA (1994) Perioperative myocardial ischemia and infarction. Int Anaesthesiol Clin 4: 115.

2. Gill NP, Wright B, Reilly CS (1992) Relationship between hypoxemia and cardiac ischemic events in the perioperative period. Br J Anaesth 68(5): 471473.

3. Vincent JC (2009) Principles of Anaesthesiology. General and Regional anaesthesia, $3^{\text {rd }}$ (Edn), Philadelphia: Lea and Fabigee 2: 1212-1223.

4. Russell WJ, Morris RG, Frewin DB, Drew SE (1981) changes in plasma catecholamine concentrations during endotracheal intubation. Br J Anaesth 53(8): 837-839. 


\section{Advances in Pharmacology and Clinical Trials}

5. Black TE, Kay B, Healy TEJ (1984) Reducing the haemodynamic responses to laryngoscopy and intubation. A comparison of Alfentanyl and Fentanyl. Anaesthesia 39(9): 883-887.

6. Wycoff C (1960) Endotracheal intubation; effects on blood pressure and pulse rate. Anaesthesiology 21(2): 153-157.

7. Raval DL, Malini KM (2002) Oral clonidine premedication for attenuation of haemodynamic response to laryngoscopy and intubation. Ind J Anaesth 46(2): 124-129.

8. Wright PM, Carabine UA, McClune S, Orr DA, Moore J (1990) Pre-anaesthetic medication with Clonidine. Br J Anaesth 65(5): 628-632.

9. Laurito CX, Baughman B, Cunningham F, Pygon $\mathrm{BH}$, Et al. (1993) Oral Clonidine blunts the haemodynamic responses to brief but not prolonged laryngoscopy. J Clin Anaesth 5(1): 54-57.

10. Giles TD, Thomas MC, Quirol A, Rice JC, Plauche W, et al. (1987) Acute and short-term effects of Clonidine in heart failure. Angiology 38(7): 537-548.

11. Hermiller JB, Magorien RD, Leithe ME, Unverferth DV, Leier CV (1983) Clonidine in congestive heart failure: a vasodilator with negative inotropic effects. Am J Cardiol 51(5): 791-795.

12. Chadha R, Padmanabhan V, Joseph A, Mohandas $K$ (1992) Oral Clonidine pretreatment for haemodynamic stability during craniotomy. Department of Anaesthesiology SCT, Trivandrum, India. Anaesthesia Intensive Care 20(3): 341-344.

13. King BD, Harris LC, Greifenstein FE, Elder JD, Dripps RD (1951) Reflex circulatory responses to direct laryngoscopy and tracheal intubation performed during general anaesthesia. Anaesthesiology 12(5): 556-66.
14. Devault M, Greifenstein FE, Harris LC (1960) Circulatory responses toendotracheal intubation in light general anesthesia-the effect of atropine and phentolamine. Anesthesiology 21: 360-362.

15. Prys Roberts C, Greene LT, Meloche R, Foëx P (1971) Studies of anaesthesia in relation to hypertension II. Hemodynamic consequences of induction and endotracheal intubation. $\mathrm{Br} \mathrm{J}$ Anaesth 43(6): 531-547.

16. Chandrashekhar PM, King R (1984) Attenuation of cardiovascular response to endotracheal intubation. Indian J Anaesth 32: 358-365.

17. Satoskar RS, Bhandarkar SD, Ainapure SS (2002) Pharmacology and Pharmacotherapeutics. 17th (Edn). Mumbai: Bombay Popular Prakashan pp: 1111.

18. Carabine UA, Wright PM, Moore J (1991) Preanaesthetic medication with clonidine: Adose-response study. Br J Anaesth 67(1): 79-83.

19. Carabine UA, Wright PM, Howe JP, Moore J (1991) Partial attenuation of the pressor response to intubation by clonidine. Anaesthesia 469: 613-707.

20. Roy S, Rudra A, Gupta K, Mondal T, Chakravorty S (1993) Attenuation of cardiovascular responses to laryngoscopy and tracheal intubation with oral clonidine (arkamine). Indian J Anaesth 41(2): 62-65.

21. Joshi VS, Vyavhare RD, Jamadar NP, Patil BM, Shiledar V (2012) Attenuation of cardiovascular responses to laryngoscopy and endotracheal intubation: Comparative evaluation of clonidine and lignocaine. IndianJ Basic Appl Med Res 1(4): 313-323.

22. Das AK, Rudra R (1995) Clinical efficacy of oral clonidine as preanaesthetic medicant. Indian J Anaesth 43(2): 133-139.

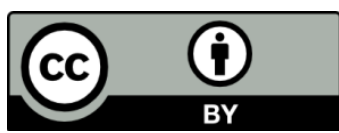

Jehangir AB, et al. Effect of Oral Clonidine on Hemodynamic Changes Due to Laryngoscopy, Intubation and Operative Procedures Stress Response. Adv Copyright $@$ Jehangir $\mathrm{AB}$, et al. Pharmacol Clin Trials 2018, 3(4): 000140. 